\title{
Bioremediation potentials of some indigenous microorganisms isolated from auto mechanic workshops on irrigation water used in lokoja kogi state of Nigeria
}

\begin{abstract}
Three (3) indigenous bacteria species (Bacillus spp, Acinectobacter spp and Moraxella spp) previously isolated from contaminated soil of some auto mechanic workshops were used for bioremediation studies on some irrigation water used at Sarkin-noma Fadama farms located in Lokoja Kogi State, Nigeria. This was done in order to investigate their bioremediation potentials using a simple pour plate method. The physicochemical parameters and heavy metal analysis (using AAS iCE 3000) of the irrigation water were performed before and after inoculation of the isolated organisms. Nitrate and phosphate concentration were found to be $10.56 \mathrm{mg} / \mathrm{L}$ and $12.63 \mathrm{mg} / \mathrm{L}$ prior to inoculation while iron and zinc were $0.9569 \mathrm{mg} / \mathrm{L}$ and $0.2245 \mathrm{mg} / \mathrm{L}$ respectively. Other physicochemical parameters were also observed to be high prior to inoculation. After the bioremediation test (inoculation with the isolated organisms), a nitrate and phosphate content of $2.53 \mathrm{mg} / \mathrm{L}$ and $2.61 \mathrm{mg} / \mathrm{L}$ were recorded respectively, iron and zinc gave $0.1694 \mathrm{mg} / \mathrm{L}$ and $0.0174 \mathrm{mg} / \mathrm{L}$ concentrations while other physicochemical parameters measured were also found to be lower in their respective values. The implication of this present study is that a number of carefully isolated indigenous bacteria species are capable of reducing the amount of heavy metal concentrations in water. Also, non-metallic contaminants like nitrate and phosphate are susceptible to bioremediation in the presence of such efficient system.
\end{abstract}

Keywords: bioremediation, heavy metals, physicochemical parameters, bacillus spp, acinectobacter spp, moraxella spp, AAS, spectrometer 3000
Volume 4 Issue 4 - 2017

\author{
Ekpa Emmanuel, Adaji Andrew Usman, Udofa \\ Daraobong, Opaluwa Queen \\ Department of Biosciences, Salem University, Nigeria
}

Correspondence: Ekpa Emmanuel, Department of Biosciences, College of Natural and Applied Sciences, Salem University, Lokoja, Nigeria, Email emmeks@yahoo.co.uk

Received: November 01, 2016 | Published: April 17, 2017

\section{Introduction}

Heavy metals are one of the most persistent pollutants in water. Unlike other pollutants, they are difficult to degrade, but can accumulate throughout the food chain, producing potential human health risks and ecological disturbances. Their presence in water is due to discharges from residential dwellings, groundwater infiltration and industrial discharges. ${ }^{1}$ The discharge of wastewater containing high concentrations of heavy metals to receiving water bodies has serious adverse environmental effects. Their occurrence and accumulation in the environment is a result of direct or indirect human activities, such as rapid industrialization, urbanization and anthropogenic sources. ${ }^{2}$ The major sources of heavy metals in water are corrosion of galvanized pipes, erosion of natural deposits, discharge from metal refineries, runoff from waste batteries and paints. Another important source of heavy metal is the production of phosphate fertilizers where part of the heavy metal ends up in the soil after the fertilizer is applied on farm lands and the rest of the heavy metals end up in surface waters when waste from fertilizer production is dumped by production companies. ${ }^{3}$ The susceptibility to heavy metals can vary greatly between aquatic organisms. Animals eating or drinking heavy metals sometimes get high blood pressure, liver disease and nerve or brain damage. Heavy metals are also gotten from the seepage, from natural oil reservoirs, domestic waste including runoff from road surfaces. In plants it decreases seed germination, plant growth, decreases enzyme activity, inhibits photosynthesis, reproductive process, water uptake, and reduces chlorophyll production Exploitation and poor management of natural resources resulting in environmental pollution is due to incessant quest of man for a better standard of living. Environmental issues such as climate change, land degradation, air and water pollution have become a major concern all over the world today. In Nigeria, environmental pollution through indiscriminate disposal of domestic, agricultural and industrial wastes without considering health and environmental implication is alarming. ${ }^{4,5}$ Heavy metal pollution is one of the most important environmental problems today. Modern industry is, to a large degree responsible for contamination of the environment. The Industrial wastes contain various types of toxic chemicals. Among toxic substances reaching hazardous levels are heavy metals. Increasing environmental pollution by heavy metals results from their increasing utilization in industrial processes. Heavy metals are dangerous because they tend to bioaccumlate. Irrigation is the artificial application of water to the land or soil. It is used to assist in growing of agricultural crops, maintenance of landscapes, and vegetation and in suppressing weed growth in grain fields and preventing soil consolation. Biological treatment is an innovative technology available for heavy metal polluted waste water. However, the water is being polluted by activities such as agricultural waste and other industrial effluents which affect the growth and function of plants, animals and even humans. Treating these pollutants therefore becomes imperative. This could be done by the use of microorganisms to degrade toxic chemicals into less toxic or non-toxic materials by natural biological process popularly referred to as bioremediation. ${ }^{6}$ 
Since microorganisms have developed survival strategies in heavy metal polluted habitats, their different microbial detoxifying mechanisms such as bioaccumulation, biotransformation, biomineralization or biosorption can be applied either ex situ or in situ to design economical bioremediation processes. In this current work, studies were carried out to examine the levels of some heavy metals, inorganic ions (nitrates and phosphates) contamination in the irrigation water used at Fadama farms located in Lokoja metropolis of Kogi State with a view to finding the bioremediating potentials of some bacteria isolated from automechanic contaminated soil on the water.

\section{Materials and methods}

\section{Sample collection site}

Sarkin-Noma Fadama farm the study area is geographically located between longitude $7^{\circ} 50^{\prime}$ and latitude $6^{\circ} 45^{\prime}$ North. It is bounded by the river Niger to the east and Sarkin-Noma village to the west in NorthWestern Lokoja, North- Central geo-political zone of the Federal Republic of Nigeria.

\section{Collection of water sample}

The water was collected from four points ( $3 \mathrm{~m}$ apart) on the sample site by using sterilized plastic containers to stir and then dipped into the river. For isolation of bacteria, $10 \mathrm{~g}$ of randomly pooled soil samples from some auto mechanic workshops was taken and serially diluted with $90 \mathrm{ml}$ of distilled water and $1 \mathrm{ml}$ each of the mixed sample was spread on plates of about-to jelled nutrient agar and incubated at $37^{\circ} \mathrm{C}$ for $24 \mathrm{hrs}$. Bacterial isolates were picked up and purified by repeated streaking on nutrient agar. Isolated bacterial strains were identified based on the morphological, cultural and biochemical characteristics (this part was done in the pilot phase of this work and has been reported elsewhere).

\section{Measurement of physicochemical parameters}

Dissolved oxygen (DO): Dissolved oxygen content in water sample was determined in $\mathrm{mg} / \mathrm{L}$ by using Winkler method. $300 \mathrm{ml}$ glass BOD stopper bottle was carefully brim filled with water sample. Immediately $2 \mathrm{ml}$ of manganous sulphate was added to the BOD bottle by inserting the calibrated pipette just below the surface of the liquid. $2 \mathrm{ml}$ of alkali-iodide-azide was then added in the same manner. The bottle was stoppered with care to ensure no air was introduced and mixed by inverting several times. $2 \mathrm{ml}$ of concentrated Sulphuric acid was added via a pipette held just above the surface of the sample. It was inverted several times to dissolve flocks. The burette was rinsed with sodium thiosulphate and then filled with same solution. $20 \mathrm{ml}$ of the solution was the measured out from the bottle and transferred to a conical flask. Titration was done against sodium thiosulphate using starch as indicator (3-4 drops). End point of the titration was the first disappearance of the blue color to colorless.

$$
\begin{aligned}
& \text { Calculation: } \mathrm{DO}=\frac{\mathrm{V} 1 \times \mathrm{N} \times 1000}{\mathrm{~V} 2} \\
& \text { Where } \mathrm{V} 1=\text { Volume of sodium thiosulphate } \\
& \mathrm{V} 2=\text { Volume of sample } \\
& \mathrm{N}=\text { normality of sodium thiosulphate } \\
& \text { Converting to mg/l multiply by } 1000
\end{aligned}
$$

Biochemical oxygen demand (BOD): Biochemical oxygen demand in water sample was determined in $\mathrm{mg} / \mathrm{L}$. The BOD measurement of water sample was the difference of oxygen concentration in the sample before and after incubation in the dark. Incubation was made at $20^{\circ} \mathrm{C}$ in BOD incubator for five day. Freshly collected water sample was diluted to about 100 times only to get measurable amount of oxygen after five days of incubation. This was filled into four BOD bottles. Initial oxygen concentration was determined immediately in two of the bottles. Remaining two bottles were incubated in BOD incubator at $20^{\circ} \mathrm{C}$ for five days, and then oxygen concentration was again determined.

\section{Calculation:}

$$
\text { BOD mg/L = D1 - D2 }
$$

Where: $\mathrm{Dl}=$ Initial oxygen value.

D2 = Oxygen value after 5days incubation.

Chemical oxygen demand (COD): Chemical oxygen demand was determined by the method of Pescod. ${ }^{8}$ It is a measure of oxygen consumed by strong oxidizing agent (Potassium dichromate) during oxidation of organic matter. Into two COD vials $2.5 \mathrm{ml}$ of the sample was added and into the third vial meant for blank distilled water was added. To the $3 \mathrm{COD}$ vials $1.5 \mathrm{ml}$ of potassium dichromate reagent digestion solution was added. Sulphuric acid reagent of $3.5 \mathrm{ml}$-catalyst solution was added. COD vials became hot. Tubes were capped slowly and the COD digester switched on and the temperature fixed at $150^{\circ} \mathrm{C}$ and heated for 2 hours. The digester automatically switch off and the vials removed and allowed to cool to room temperature. Burette was filled with ferrous ammonium sulphate solution, adjusted to zero. The content of the blank vial was transferred into a conical flask, few drops of ferroin indicator was added which resulted in a bluish green color. It was afterwards titrated with the ferrous ammonium sulphate in the burette. End point of titration was the appearance of reddish brown color. This was also carried out on the water sample.

\section{Calculation:}

$\mathrm{COD}=\underline{(\mathrm{A}-\mathrm{B}) \times \mathrm{N} \times 8 \times 1000}$

$\mathrm{V}$

Where: $\mathrm{A}=$ Volume of ferrous ammonium sulphate for blank

$B=$ Volume of ferrous ammonium sulphate for sample

$\mathrm{N}=$ Normality of ferrous ammonium sulphate

$\mathrm{V}=$ Volume of sample taken.

To convert the sample size from $\mathrm{ml}$ to 1 multiply by 1000

pH: The water sample of about $25 \mathrm{ml}$ was transferred into a beaker and swirled continuously for uniform mixture, afterwards the electrode of the calibrated $\mathrm{pH}$ meter was then immersed into the sample and the $\mathrm{pH}$ recorded when the meter reading was stable.

Electrical Conductivity (EC): The EC meter was turned on and the probe calibrated using a standard solution of known conductivity. The probe was thoroughly rinsed before and after calibration using deionized water and carefully blots dried using cotton wool. Water sample was transferred into a beaker and the probe submerged into the sample. The EC was recorded when the EC reading on the meter became stable Monica (2014). 


\section{Phosphate}

The method described by Rima ${ }^{9}$ was employed.

\section{Preparation of calibration curve}

Standard stock solution of phosphorus of $100 \mathrm{mg} / \mathrm{dm}^{3}$ was prepared by dissolving $0.11 \mathrm{~g}$ of $\mathrm{KH} 2 \mathrm{PO} 4$ in distilled water and diluting to $250 \mathrm{~cm}^{3}$ in a volumetric flask (Stock Solution A). $10 \mathrm{~cm}^{3}$ of this solution was accurately transferred to a $250 \mathrm{~cm} 3$ volumetric flask and made up to volume with distilled water (Stock solution B). Stock solution B was used to prepare standards of approximately $0.20,0.40$, $0.60,0.80$ and $1.0 \mathrm{mg} \mathrm{P} / \mathrm{dm}^{3}$, that is, $5,10,15,20$ and $25 \mathrm{~cm}^{3}$ portions was pipette respectively to separate labeled $100 \mathrm{~cm}^{3}$ volumetric flasks. Then $50 \mathrm{~cm}^{3}$ of distilled water was placed into a $100 \mathrm{~cm}^{3}$ flask as a blank solution, then all the analytical solutions were organized for color development. Solutions were not made up to the mark yet

\section{Analysis of water sample}

Duplicate $25.0 \mathrm{~cm} 3$ portions of the sample with a dilution factor of 10 was pipetted into two separate $100 \mathrm{~cm} 3$ volumetric flask, then the color was developed as outlined below.

\section{Color development}

Distilled water was added to all the analytical solutions (standards and samples) so that each flask contained roughly $50 \mathrm{~cm} 3$ of solution. Starting with standard $1,13 \mathrm{~cm} 3$ of combined reagent was added using a $25 \mathrm{~cm} 3$ measuring cylinder (Note 1) mixed thoroughly and made up to the mark with distilled water. All the solutions were treated similarly and then allowed to stand for 30 minutes for color development. The absorbance of the standards was measured in order of increasing concentration followed by that of the sample solutions, using water as blank.

\section{Nitrate}

The UV-spectrophotometric method was used for the determination of nitrate content of water sample.

\section{Preparation of reagent $A$}

$5 \mathrm{~g}$ of salicylic acid was dissolved in $96 \%$ Sulphuric acid and filled up to $100 \mathrm{ml}$ with $96 \%$ Sulphuric acid.

\section{Preparation of reagent $\mathbf{B}$}

$40 \mathrm{~g}$ of $\mathrm{NaOH}$ was dissolved in deionized water and filled up to $500 \mathrm{ml}$ with deionized water.

\section{Preparation of standard solution}

$0.0680 \mathrm{~g}$ of sodium nitrate was dissolved in deionized water and made up to $100 \mathrm{ml}$ with deionized water (concentration of sodium nitrate is $8.0 \mathrm{mM}$ ). The standard solution was diluted with deionized water in a range of: $0 ; 0.1 ; 0.2 ; 0.5 ; 1.0 ; 2.0 ; 4.0$ and $6.0 \mathrm{mM}$ nitrate. $0.8 \mathrm{ml}$ of reagent 1 was added to $0.2 \mathrm{ml}$ standard or sample and mixed properly. It was left for 20 minutes at room temperature. $19 \mathrm{ml}$ of reagent 2 was added slowly and mixed properly. It was allowed to cool to room temperature with a yellow color which was stable for 48 hours. The absorption was measured at $410 \mathrm{~nm}$ with a spectrophotometer.

\section{Heavy metal analysis of water sample}

The estimation of heavy metals was done using Computer
Controlled Atomic Absorption Spectrometer (AAS iCE 3000). Firstly, $1 \mathrm{ml}$ of the sample was taken and digested with $10 \mathrm{ml}$ of nitric acid and after complete digestion the volume was made up to $100 \mathrm{ml}$ with deionized water in a volumetric flask, filtered and stored in a polypropylene container. The samples were then analyzed with computer Controlled Atomic Absorption Spectrophotometer.

\section{Bioremediation studies using the isolated indigenous microorganisms}

About $20 \mathrm{cfu} / \mathrm{ml}$ of the individual isolated strains of microorganism were inoculated into $500 \mathrm{ml}$ of the irrigation water in a sterilized plastic container and left in the incubator for a week. Physicochemical parameters and heavy metal analysis were carried out on the inoculated water sample to determine the differences before and after the introduction of the organisms. Heavy metal and physicochemical analysis were then carried out to study the bioremediation potential of the bacteria.

\section{Results and discussion}

The results represented in Tables $1 \& 2$ shows the effect of adding the isolated microorganisms in the irrigation water. In Table 1, all the values except for $\mathrm{pH}$ are above the normal range for normal water suggesting that the source of this water which might be due to some industrial discharges and other human activities may have contributed to the pollution observed. According to Pescod, ${ }^{8}$ irrigation water is not supposed to have a higher than normal nitrate content because of its toxicity to the final consumers of the irrigated crops. In Table 2 (before inoculation), it was observed that iron had a higher value $(0.9569 \mathrm{mg} / \mathrm{L})$ above the standard for normal water of $0.3 \mathrm{mg} /$ $\mathrm{L}^{10}$ probably because of the geology of Lokoja town which is rich in iron ore deposits as evidenced by the number of iron ore mining sites scattered across Kogi State. Since water bodies could be due to the runoff of surface waters to the rivers, the possibility of iron at higher concentrations in this irrigation water is not far-fetched. The other heavy metals ( $\mathrm{Cd}$ and $\mathrm{Cr}$ ) observed before the inoculation show less significance which might be due to their rare occurrence in most environments. After the bioremediation test was carried out (inoculation with the isolated microbes) there was a significant reduction in the values of all the determined parameters. This is simply a reflection of the bioremediating potentials of the isolated organisms (Moraxella spp, Bacillus spp, and Acinectobacter spp) which have been implicated in different bioremediation studies. ${ }^{11}$ Some of the values of physicochemical parameters like DO, BOD, and COD do support the growth of this microbes. Hence, their high rate of metabolism which eventually enhances their degradation capacities. Phosphate and nitrates are also good sources of nutrients for microorganisms generally, but this work shows that at elevated concentrations (above $5 \mathrm{mg} / \mathrm{L}$ and $10 \mathrm{mg} / \mathrm{L}$ respectively) as shown in Table 1, they could become toxic to the crops and eventually their final consumers. ${ }^{11}$ However, the ability of this isolated microorganisms to reduce the phosphate and nitrate contents as seen in Table 2 shows that they possess some bioremediation potentials. The reduction in nitrate and phosphate could also be due to their suitability as sources of nitrogen and phosphorous for the organisms. The role of Acinectobacter for example in nitrogen cycle could have also contributed to the observed reduction in the nitrate content of the pre and post inoculated water used (Table 1). Bacillus generally is a good degrader of most environmental pollutants. When the percentage reduction (bioremediation values) were computed, it was shown 
that zinc was reduced by $92 \%$ followed by iron $82 \%$ while lead was lowest by $30 \%$. In most bioremediating organisms, and also because of the geological nature of the Niger River, it is possible that zinc was highly metabolized due to its role as essential micronutrients for these organisms and for its redox potentials. Iron closely followed Zinc probably because of its chelating properties and its predominance in the Lokoja terrain. ${ }^{12}$ The perceived low values for lead could be due to the fact that lead and other metals such as silver and aluminum are non-essential and potentially toxic to most soil and aquatic microorganisms. Within the scope of this study, potentials exist in the utilization of these indigenous microorganisms to bioremediate some toxic heavy metals and non-metallic ions that might be present in irrigation water and thereby ensure a sustainable safety in the consumption of irrigated crops (Table 3).

Table I Physicochemical analysis of water sample (before and after innoculation)

\begin{tabular}{lllll}
\hline Parameters & (Before innoculation) & (After innoculation) & \\
\hline $\mathrm{pH}$ & 6.89 & 7.02 & \\
Conductivity $(\mu \mathrm{scm})$ & & 165 & & \\
$\mathrm{BOD}(\mathrm{mg} / \mathrm{L})$ & 207 & 11.4 & & \\
$\mathrm{COD}(\mathrm{mg} / \mathrm{L})$ & 12.62 & 2.05 & 10.56 & 2.53 \\
$\mathrm{DO}(\mathrm{mg} / \mathrm{L})$ & 2.35 & 8.32 & & \\
Phosphate $(\mathrm{mg} / \mathrm{L})$ & 8.98 & 2.61 & \\
Nitrate $(\mathrm{mg} / \mathrm{L})$ & 12.63 & & \\
\hline
\end{tabular}

Table 2 Heavy metal analysis of irrigation water before and after Key: ND, not detected

\begin{tabular}{lll}
\hline Heavy metals & Concentration $(\mathbf{m g} / \mathbf{L})($ Before innoculation) & Concentration $(\mathbf{m g} / \mathbf{L})($ After innoculation) \\
\hline Cadmium $(\mathrm{Cd})$ & $\mathrm{ND}$ & $\mathrm{ND}$ \\
Zinc $(\mathrm{Zn})$ & 0.2245 & 0.017492 \\
Lead $(\mathrm{Pb})$ & 0.0294 & 0.022730 \\
Iron $(\mathrm{Fe})$ & 0.9569 & 0.169482 \\
\hline
\end{tabular}

Table 3 Biochemical characterization of isolated bacteria

\begin{tabular}{llllllll}
\hline S/N & $\begin{array}{l}\text { Gram } \\
\text { staining }\end{array}$ & Catalase & Indole & $\begin{array}{l}\text { Citrate } \\
\text { utilization }\end{array}$ & Oxidase & $\begin{array}{l}\text { Sugar } \\
\text { utilization }\end{array}$ & $\begin{array}{l}\text { Identified } \\
\text { bacteria }\end{array}$ \\
\hline 1 & - Cocci & + & - & + & - & + & Acinectobacter spp \\
2 & - Bacilli & + & - & + & - & + & Bacillus spp \\
3 & - Bacilli & + & - & + & + & + & Moraxella spp \\
\hline
\end{tabular}

\section{Acknowledgements}

None.

\section{Conflict of interest}

The author declares no conflict of interest.

\section{References}

1. Agwu A, Kalu AU. Bioremediation and environmental sustainability in Nigeria. International Journal of Academic Research in Progressive Education and Development. 2012;1(3):2226-6348.

2. Enekola SO, Salifu E. Evaluation of ground water quality for fadama irrigation lands in river niger-benue confluence of Lokoja-Nigeria. International Journal of Scientific and Research Publications. 2012;2(9):2250-3153.

3. Jackson VA, Paulse AN, Odendaal JP. Identification of Metal-tolerant Organisms Isolated from the Plankenburg River, Western Cape, South Africa. AJOL. 2012;38(1):50.
4. Kocialkowski WZ, Diatta JB, Greebise W. Evaluation of chelating agents as heavy metals extractants in agricultural soils under threat of contamination. Polish Journal of Environmental Studies. 1999;8(3):149154.

5. Kumaran NS, Sundaramanickam A, Bragadeeswaran S. Absorption studies on heavy metals by isolated bacterial strain (pseudomonas $s p$ ) from uppanar estuarine water, southeast coast of India. Journal of Applied Sciences in Environmental Sanitation. 2011;6(4):471-476.

6. Manisha N, Dinesh S, Arun K. Removal of heavy metals from industrial effluent using bacteria. International Journal of Environmental Sciences. 2011;2(2):1-7.

7. Napur R, Shrivastava JN. Remediation of yamuna river water in city of taj by bacterial consortium. International Journal of Pure \& Applied Biosciences. 2014;2(2):249-253.

8. Pescod MB. Wastewater treatment and use in agriculture. UK: Food and Agriculture Organization of the United Nations Press; 1992. 56 p.

9. Riina T. Interactions between metals, microbes and plants-bioremediation 
of arsenic and lead contaminated soils. Finland: Academic Dissertation in Environmental Ecology, Department of Ecological and Environmental Sciences, University of Helsinki; 2002.

10. United State Environmental Protection Agency. In situ Bioremediation. Environmental Protection emergency response, EPA 542-f-01-001. 2003.
11. United State Environmental protection Agency. In situ and ex situ biodegradation technologies for contaminated sites. Office of Research and Development EPA 625-R-06-015. 2006.

12. United State Environmental Protection Agency. Maximum contaminant level standard for drinking water. Office of Solid Waste and Emergency Response EPA 816-F-09-004. 2009. 